\title{
Levendefødte i Norge 1967-76 med diagnosen Down syndrom - en registerstudie
}

\author{
Tor Bjerkedal $^{1}$ og Petter Kristensen ${ }^{2,3}$ \\ 1) Institutt for epidemiologi, Forsvarets sanitet, Oslo \\ 2) Statens arbeidsmiljøinstitutt, Oslo \\ 3) Seksjon for forebyggende medisin, Universitetet i Oslo \\ Korrespondanse: Tor Bjerkedal, FSAN/MEDOPS, Ullevål universitetssykehus, Oslo mil/Akershus, 0015 Oslo \\ Telefon: 23015344 telefax: 23015351 e-post: tbjerkedal@mil.no
}

\begin{abstract}
SAMMENDRAG
Diagnoser av Down syndrom registrert i Medisinsk fødselsregister (MFR) er sammenholdt med diagnoser registrert i stønadsregistrene i Ny arbeids- og velferdsetat (NAV), tidligere Rikstrygdeverket for alle levendefødte i årene 1967-76, i alt 629 928. Formålet med studien har vært å vurdere hvor ofte diagnosen Down syndrom registreres i MFR i forhold til forekomsten av tilstanden og validiteten av diagnosene, og å følge opp sannsynlige tilfeller av Down syndrom til ung voksen alder i forhold til overlevelse, utdanning, arbeidsaktivitet, uførepensjonering og familiedannelse. Oppfølgingen er muliggjort ved registerkoblinger, godkjent av Datatilsynet og utført av Statistisk sentralbyrå. Totalt var diagnosen Down syndrom registrert i 784 tilfeller, 1,25 per 1000 levendefødte, noe høyere for gutter, 1,31, enn for piker 1,19. Falske positive i MFR utgjorde 4,9 prosent mens falske negative er anslått til 27,8 prosent. Det vil si at 72,2 prosent av Down syndrom tilfellene blir diagnostisert ved fødsel og registrert i MFR. Dette anslag er beheftet med atskillig usikkerhet. Usikkerheten skyldes omfanget av fosterindisert abort, uensartet diagnostikk, varierende meldefrekvens og mangelfull registrering. Å redusere usikkerheten ville kreve systematisk tilgang til relevante helseregistre og at helsevesenets samlede kunnskap om personer med definerte lidelser kan innhentes løpende. Personvern, slik dette forståes og praktiseres i dag, vil sannsynligvis hindre en slik løsning. En systematisk oppfølging er imidlertid viktig for velferden for utsatte grupper i vårt samfunn. I foreliggende undersøkelse kan det dokumenteres at personer med Down syndrom ikke oppnår den arbeidsaktivitet som utdanningen de har gjennomført skulle tilsi. At noen få tilfeller ikke synes å være uførepensjonert før 30-års alderen kan også være et interessant funn. En avklaring på dette forhold kunne gi nyttig informasjon for velferdsarbeidet for personer med Down syndrom.
\end{abstract}

\section{Bjerkedal T, Kristensen P. Live born in Norway 1967-76 with the diagnosis of Down syndrome. Nor J Epidemiol 2007; 17 (2): 157-164.}

\section{ENGLISH SUMMARY}

The purpose of the present study was to investigate reliability and validity of the diagnoses of Down syndrome in the Medical Birth Registry of Norway (MBRN). In addition we wanted to perform a follow-up of persons who most likely had Down syndrome with respect to survival, education, participation in the labor force and income. The material comprises all live born registered in MBRN during the years 1967-76, a total of 626928 infants. Diagnoses of Down syndrome in MBRN (N=593) were collated with diagnoses in the benefit registries of the National Insurance Administration (NAV) (N=574). Additional information for the follow-up was provided by matching with a number of national registries: Central Population Register (survival, immigration), Education register of Statistics Norway, NAV's Register of annual income and Norwegian Armed Forces personnel data base (conscription, military service). Using two sources of the diagnoses of Down syndrome still left considerable uncertainty in estimating the prevalence of the condition. About 72 per cent of the cases were registered in MBRN. In the follow-up Down syndrome cases were found to have an especially high mortality during the first years of life. Their educational achievement was less. Even with especially adapted education, which most of the Down syndrome cases had received, they failed to become economically active to any appreciable extent. Most of them received disability pension before they were 30 years. The few who did not are interesting and their situation should be further explored.

\section{INNLEDNING}

Innføringen av "Medisinsk registrering av fødsel" i 1967 hadde til formål å fremskaffe et datagrunnlag for å overvåke forekomsten av medfødte misdannelser (1). Data- grunnlaget skulle også tjene til å redusere den perinatale dødelighet og danne utgangspunkt for oppfølging av nyfødte med spesielle problemer. Et system for overvåking av forekomsten av medfødte misdannelser kom raskt $i$ gang etter etableringen av Det medisinske fødsel- 
register (MFR) i 1969 (2,3). Etter innføringen av den medisinske fødselsmelding er den perinatale dødelighet redusert fra ca. 20,6 per 1000 fødte i 1967 til 5,1 i 2003 $(4,5)$. Det har ikke lykkes å etablere en systematisk oppfølging av nyfødte med spesielle problemer. Riktignok har MFR fra 1999 mottatt data fra landets neonatalavdelinger for de barn som overflyttes i forbindelse med fødselen (5), men denne meldingen er et bidrag til kvalitetssikring av data om de nyfødte og representerer ikke egentlig noen oppfølging. En systematisk oppfølging kunne bidra til at nyfødte med erkjente problemer får en adekvat behandling og omsorg. I tillegg kunne en systematisk oppfølging tjene til å avklare forhold knyttet til spørsmål om reliabiliteten og validiteten av de registreringer MFR bygger på (6).

I dagens situasjon foreligger det en mulighet til å ivareta slike formål ved å koble MFR med andre nasjonale registre som inneholder opplysninger om individers helseforhold. I Forskriften for MFR er det tilrettelagt for slike koblinger (7).

I denne artikkel sammenholdes diagnosene av Down syndrom i MFR med diagnosene av Down syndrom registrert i Ny arbeids- og velferdsetat (NAV), tidligere Rikstrygdeverket, i forbindelse med innvilgede søknader. Diagnosenes pålitelighet for estimering av forekomsten av Down syndrom blant levendefødte søkes klarlagt og sannsynlige tilfeller av Down syndrom er identifisert for oppfølging med hensyn til overlevelse, utdanning, arbeidsaktivitet, uførepensjonering og antall barn. Resultatene diskuteres ut fra anvendeligheten av registreringene i MFR for estimering av forekomst og oppfølging av barn med spesifikke medfødte misdannelser og andre lidelser som erkjennes i neonatalperioden.

\section{Materiale}

Materialet omfatter alle levendefødte i Norge i perioden 1967-76 registrert i MFR, i alt 626 928. Med fødselsnummer for barn og deres foreldre ble det foretatt koblinger mot NAVs stønadsregistre og register over pensjonsgivende inntekt, mot Statistisk sentralbyrås (SSBs) utdanningsregister, mot Folkeregisteret (bosted, utvandring og død) og mot Forsvarets personelldatabase (sesjon og førstegangstjeneste for menn).

De dataansvarlige har gitt tillatelse til bruk av data. Statistisk sentralbyrå har foretatt koblingene og anonymisert filen før utlevering for analyser. Datatilsynet har gitt konsesjon. Den regionale etiske komité for forskning har godkjent hovedformålet med undersøkelsen.

Identifisering av personer med diagnosen Down syndrom ble foretatt ved søk i MFR og i NAVs stønadsregister. For analytiske formål ble materialet delt $\mathrm{i}$ tre grupper: (1) Diagnosen bare fra MFR, (2) Diagnosen fra både MFR og NAV og (3) Diagnosen bare fra NAV. Diagnoser i MFR bygger på de lokale fødeavdelingers notering på fødselsmeldingen av observerte medfødte misdannelser i neonatalperioden. Disse ble kodet sentralt i MFR. I den aktuelle perioden ble ICD 8 benyttet med koden 759.3 for Down syndrom. Når det gjelder medisinske begrunnelser for grunn- og eller hjelpestønad ble disse kodet i de lokale trygdekontorer og kodene registrert sentralt. Legeerklæringer som lå til grunn for vedtak om uførepensjon ble sendt til NAV og kodet der. Følgende diagnosekoder for Down syndrom ble benyttet i aktuelle tidsperioder: ICD 7-325.4, ICD 8-759.3, ICD 9-758.0 og ICD 10-Q90.0-9.

På utvalgte alderstrinn er personer med diagnosen Down syndrom sammenliknet med alle andre med hensyn til uførepensjonering frem til 2006 (30-års alder for fødte i 1976, henholdsvis 39-års alder for fødte i 1967), overlevelse og pensjonsgivende inntekt til 2003 (27-36-års alder); høyeste utdanning per 2001 (25-34-års alder) og andelene av kvinner og menn med minst ett barn er basert på fødte registrert i MFR frem til 1998. Data fra sesjon og førstegangstjeneste gjelder menn som var i live ved alder 18 år.

Årlig inntekt registreres i NAV og danner grunnlaget for utregning av pensjon. Den pensjonsgivende del av inntekten blir omregnet i grunnbeløp $(\mathrm{G})$ som justeres regelmessig i takt med den generelle lønnsutvikling.

Utdanning er hentet fra Statistisk sentralbyrås utdanningsregister. Høyeste utdanning registrert i 2001 er benyttet. Første siffer i utdanningsgrupperingen (8) er brukt til å definere "Høyere utdanning": Nivå 5 (påbygging til videregående) og høyere, og "Lavere utdanning" som omfatter nivå 4 (videregående, avsluttende) og lavere. Uoppgitt utdanning og ingen utdanning er samlet $i$ egen gruppe.

Ut fra fødselsnumre for fødte i 1967-76 er deres barn identifisert i MFR frem til 1998. Andel med minst en registrert fødsel i perioden fram til 1998 er benyttet som indeks for familiedannelse.

Alder er angitt ved antall fylte år ved utgangen av året, dvs. aktuelt år minus fødselsår.

Analysene bygger på vanlig deskriptiv statistikk og resultatene presenteres i tabeller og figurer. Cronbachs alfa er benyttet som mål for samsvar i registreringen av diagnosen Down syndrom i de to kilder, MFR og NAV.

\section{RESUlTATER}

\section{Forekomst av diagnosen Down syndrom}

Antall diagnoser av Down syndrom registrert i MFR og/eller NAV vil fremgå av tabell 1. Av de i alt 784 diagnoser var 26,8 prosent bare registrert i MFR, 48,9 prosent både i MFR og NAV og 24,4 prosent bare i NAV. Det betyr at 75,8 prosent av alle diagnoser av Down syndrom som er identifisert i de to registre kommer fra MFR. Cronbachs alfa for diagnosen fra de to kildene var 0,79. Ved fødsel var andelen som ble registrert med diagnosen Down syndrom 0,93 per 1000 levende fødte gutter og noe høyere, 0,96, for piker. Med tillegg av diagnoser registrert bare i NAV med henholdsvis 123 gutter og 68 piker, blir forekomsten 
Tabell 1. Antall diagnoser av Down syndrom blant levendefødte i Norge 1967-76 registrert i MFR og NAV.

\begin{tabular}{|c|c|c|c|c|c|c|}
\hline \multirow[b]{2}{*}{ Kilde for diagnosen } & \multicolumn{2}{|c|}{ Gutter } & \multicolumn{2}{|c|}{ Piker } & \multicolumn{2}{|c|}{ Alle } \\
\hline & Antall & Prosent & Antall & Prosent & Antall & Prosent \\
\hline Bare MFR & 92 & 21,8 & 118 & 32,6 & 210 & 26,8 \\
\hline Både MFR og NAV & 207 & 49,1 & 176 & 48,6 & 383 & 48,9 \\
\hline MFR i alt & 299 & 70,9 & 294 & 81,2 & 593 & 75,6 \\
\hline Bare NAV & 123 & 29,1 & 68 & 18,8 & 191 & 24,4 \\
\hline Antall diagnoser, i alt & 422 & 100,0 & 362 & 100,0 & 784 & 100,0 \\
\hline Per 1000 levendefødte & 1,31 & & 1,19 & & 1,25 & \\
\hline
\end{tabular}

Tabell 2. Kilde for diagnosen Down syndrom blant fødte i Norge 1967-76 etter bostedsregion ved fødsel.

\begin{tabular}{|c|c|c|c|c|c|c|c|c|}
\hline \multirow[b]{2}{*}{ Region (Fylker) } & & \multicolumn{3}{|c|}{ Kilde for Down syndrom diagnosen } & \multicolumn{2}{|c|}{ Down syndrom i alt } & \multirow{2}{*}{$\begin{array}{c}\text { Alle andre } \\
\text { Antall }\end{array}$} & \multirow{2}{*}{$\begin{array}{l}\text { Totalt } \\
\text { Antall } \\
\end{array}$} \\
\hline & & Bare MFR & $\begin{array}{c}\text { Både MFR } \\
\text { og NAV }\end{array}$ & Bare NAV & Antall & Per 1000 & & \\
\hline \multirow{2}{*}{ Oslo + Akershus $(2,3)$} & Antall & 53 & 73 & 19 & 145 & 0,97 & 149816 & 149961 \\
\hline & Prosent & 36,6 & 50,3 & 13,1 & 100,0 & & & \\
\hline \multirow{2}{*}{$\begin{array}{l}\text { Østlandet ellers } \\
(1,4,5,6,7,8)\end{array}$} & Antall & 61 & 130 & 52 & 243 & 1,20 & 201802 & 202045 \\
\hline & Prosent & 25,1 & 53,5 & 21,4 & 100,0 & & & \\
\hline \multirow[t]{2}{*}{ Sør-Norge $(9,10,11)$} & Antall & 28 & 47 & 27 & 102 & 1,16 & 88064 & 88166 \\
\hline & Prosent & 27,5 & 46,1 & 26,5 & 100,0 & & & \\
\hline \multirow[t]{2}{*}{ Vest-Norge $(12,14)$} & Antall & 14 & 32 & 40 & 86 & 1,13 & 76033 & 76119 \\
\hline & Prosent & 16,3 & 37,2 & 46,5 & 100,0 & & & \\
\hline \multirow[t]{2}{*}{ Midt-Norge $(15,16,17)$} & Antall & 37 & 78 & 22 & 137 & 1,59 & 86030 & 86167 \\
\hline & Prosent & 27,0 & 56,9 & 16,1 & 100,0 & & & \\
\hline \multirow[t]{2}{*}{ Nord-Norge $(18,19,20)$} & Antall & 25 & 43 & 36 & 104 & 1,60 & 64916 & 65020 \\
\hline & Prosent & 24,0 & 41,3 & 34,6 & 100,0 & & & \\
\hline \multirow[t]{2}{*}{ Total } & Antall & 210 & 383 & 191 & 784 & 1,25 & 626144 & 626928 \\
\hline & Prosent & 26,8 & 48,9 & 24,4 & 100,0 & & & \\
\hline
\end{tabular}

av diagnosen Down syndrom høyere blant gutter. Imidlertid var det $\mathrm{i}$ foreliggende materiale ikke registrert en diagnose ved alle innvilgede stønader. Bortfallet av diagnoser varierer med type av stønad, kjønn og over tid. For menn var bortfallet ved grunn- og/eller hjelpestønad totalt frem t.o.m. 2003 12,8 prosent og for kvinner 18,0. Under forutsetning av at bortfallet ikke var selektivt kan det antas at andelen med diagnosen Down syndrom er den samme blant dem uten registrert diagnose som blant dem med registrert diagnose. Korrigeres det for denne svikt i diagnoseregistrering i NAV vil antallet med Down syndrom tilfeller fra bare NAV øke med 16 til totalt 139 for gutter og med 12 til 80 for piker. Økningen vil redusere andelen av diagnoser fra MFR fra 75,8 til 73,0 prosent.

Forekomsten av registrerte diagnoser av Down syndrom varierer noe etter føderegion. Oslo og Akershus har den laveste forekomsten, 0,97 per 1000 levende fødte. Nord-Norge har den høyeste 1,60 (tabell 2).

Andelen med kilde for diagnosen bare fra NAV er spesielt høy i Vest-Norge, 46,5 prosent mot et landsgjennomsnitt på 24,4. Det kan tyde på at den lavere forekomsten av medfødte misdannelser som er regi- strert i MFR for Vest-Norges vedkommende i de aktuelle år, 13,0 per 1000 fødte med misdannelse mot 21,5 i landet for øvrig (9), også gjelder for Down syndrom. Mest sannsynlig er forklaringen en underrapportering på den Medisinske fødselsmelding av størrelsesorden 22 prosent og ikke en reelt lavere forekomst. Med supplering fra andre kilder blir forekomsten av diagnosen Down syndrom i Vest-Norge ikke vesentlig forskjellig fra andre regioner.

\section{Vurdering av Down syndrom diagnosenes pålitelighet}

Det er rimelig å anta at diagnosen Down syndrom for en person er korrekt hvis den finnes $i$ to uavhengige registre, både i MFR og NAV. Finnes den bare i ett av registrene kreves en uavhengig kilde for å vurdere om diagnosen er korrekt. Vi har benyttet tilgjengelige data fra Vernepliktverkets om sesjon og førstegangstjeneste for menn.

Det var $56(17,3 \%)$ av de i alt 324 menn med diagnosen Down syndrom som var i live/bosatt ved 18 år og møtte til sesjon (tabell 3). Av disse ble ni kjent tjenestedyktig og syv av disse ble innkalt til førstegangstjeneste som for alles vedkommende ble fullført. Seks 
Tabell 3. Gjennomføring av sesjon og førstegangstjeneste for menn født i Norge 1967-76 som var i live og bosatt ved 18-års alder.

\begin{tabular}{|c|c|c|c|c|c|c|}
\hline \multirow{2}{*}{ Kategori } & & \multicolumn{4}{|c|}{ Kilde for Down syndrom diagnosen } & \multirow[b]{2}{*}{ Alle andre } \\
\hline & & Bare MFR & $\begin{array}{c}\text { Både MFR } \\
\text { og NAV }\end{array}$ & Bare NAV & I alt & \\
\hline \multicolumn{2}{|c|}{ Menn i live/bosatt ved 18-års alder } & 13 & 197 & 114 & 324 & 312450 \\
\hline \multirow[t]{2}{*}{ Møtt på sesjon } & Antall & 8 & 26 & 22 & 56 & 304847 \\
\hline & Prosent & 61,5 & 13,2 & 19,3 & 17,3 & 97,6 \\
\hline \multirow[t]{2}{*}{ Kjent tjenestedyktig } & Antall & 6 & 1 & 2 & 9 & 298179 \\
\hline & Prosent av fremmøtte & 75,0 & 3,8 & 9,1 & 16,1 & 97,8 \\
\hline \multirow[t]{2}{*}{ Innkalt til 1.gangstjeneste } & Antall & 6 & 0 & 1 & 7 & 227774 \\
\hline & Prosent av tjestedyktige & 100,0 & 0,0 & 50,0 & 77,8 & 76,4 \\
\hline \multirow[t]{2}{*}{ Fullført 1.gangstjenesten } & Antall & 6 & 0 & 1 & 7 & 213857 \\
\hline & Prosent av innkalte & 100,0 & 0,0 & 100,0 & 100,0 & 93,9 \\
\hline
\end{tabular}

av de som fullførte førstegangstjenesten hadde diagnosen Down syndrom bare fra MFR, mens en hadde diagnosen bare fra NAV. Den medisinske journal fra førstegangstjenesten for de syv inneholder ingen opplysninger som kunne tyde på at noen av dem har hatt Down syndrom. Det gir en klar indikasjon på at diagnosen er feil. I diagnostisk terminologi benevnes tilfellene som "falske positive". Ingen av de syv er blitt uførepensjonert. Alle syv har en høyeste utdanning i 25-års alderen på nivå 4 (videregående, avsluttende) eller høyere. De har også en pensjonsgivende inntekt ved 27-års alder i gruppe 4 (3,5-4,49 G) eller høyere, unntatt for en som ikke hadde noen pensjonsgivende inntekt for dette året.

For kvinner har vi ikke en uavhengig datakilde for vurdering av diagnosen Down syndrom. Benytter vi to av kjennemerkene som ble funnet for de syv menn med uriktig diagnose (dvs. ikke uførepensjonert og utdanningsnivå høyere enn nivå 3 ved 25-års alder) som seleksjonskriterier på totalmaterialet finner vi at 23 kvinner har en Down syndrom diagnose som sannsynlig er "falsk positiv". For alle 23 var diagnosen bare fra MFR. I tillegg til de syv menn med fullført førstegangstjeneste ble det identifisert en åttende med sannsynlig falsk positiv diagnose. Vedkommende var registrert med diagnosen Down syndrom bare fra NAV. Etter denne vurdering blir antall Down syndrom redusert med åtte gutter og 23 piker.

Dette betyr at av de 593 Down syndrom diagnoser som var registrert i MFR var 29 (4,9\%) falske positive. Av de 191 diagnoser som bare var registrert i NAV var to falske positive. Antas de resterende 189 diagnoser av Down syndrom fra NAV å være korrekte og legges til antatt manglende diagnoser av Down syndrom i NAV, 28, blir anslaget for falske negative i MFR 27,8 prosent. Med andre ord synes 72,2 prosent av Down syndrom tilfellene å bli registrert ved fødsel.

\section{Oppfolging av personer med sannsynlig Down syndrom}

Oppfølgingen må baseres på identifiserte tilfeller med diagnosen Down syndrom med fradrag av sannsynlig
31 falske positive ( 8 menn og 23 kvinner) og omfatter $i$ alt 753, 414 gutter og 339 piker.

I live og bosatt ved utvalgte aldre

Tabell 4 gir antallet i gruppene som var i live og bosatt ved utvalgte aldre. Sammenlikningene er basert på disse tallene. Antallet er fremkommet ved å trekke fra døde og utvandrede før angjeldende aldre. For personer med Down syndrom er det bare to kvinner som er utvandret før 27-års alder, mens 206 (27,4\%) personer er døde. For alle andre er tallene for utvandrede 10828 (1,7\%), henholdsvis 14994 døde $(2,4 \%)$.

Overlevelse til 2003 (alder 27-36 år)

Figur 1 viser en betydelig overdødelighet i de første leveår av personer med sannsynlig Down syndrom. Fra 5-års alderen og frem til 27-års alderen er dødelighet om lag 3,7 ganger høyere enn for alle andre.

\section{Uførepensjonering}

Figur 2 viser at personer med sannsynlig Down syndrom raskt uførepensjoneres fra alder 16 år inntil slutten av 20-årene. Da flater kurvene ut. Avflating indikerer at to menn $(0,6$ prosent av dem som var i live og bosatt ved 16-års alderen) og ni kvinner $(3,6 \%)$ ikke er blitt uførepensjonert innen utgangen av 2006. I gruppen med diagnosen Down syndrom bare fra MFR ble 21 uførepensjonert uten at diagnosen Down syndrom er registrert hos NAV. Av de 21 var det 11 helt uten registrert diagnose, åtte med diagnoser som anga andre spesifiserte misdannelser og psykisk utviklingshemning og to med andre diagnoser,

\section{Utdanning ved 25-års alder}

Antall menn og kvinner som var i live og bosatt ved 25 år alder og som kan sammenliknes hva angår høyeste utdanning ved denne alder vil fremgå av tabell 4 . Defineres "høyere utdanning" med nivå 5 (påbygging til videregående) (8) og høyere, hadde ingen med sannsynlig Down syndrom høyere utdanning (tabell 5). Av dem med kjent utdanning var 94 prosent registrert med nivå 3 (videregående, grunnutdanning). På dette nivå er det spesifisert en serie særskilt tilrettelagte 
Tabell 4. Antall og prosent i live og bosatt* ved utvalgte alderstrinn av fødte i Norge med sannsynlig Down syndrom og alle andre.

\begin{tabular}{ccccccc}
\hline I live og bosatt & \multicolumn{3}{c}{ Sannsynlig Down syndrom } & \multicolumn{3}{c}{ Alle andre } \\
\cline { 2 - 6 } ved alder (år) & Menn & Kvinner & I alt & Menn & Kvinner & I alt \\
\hline & & & \multicolumn{5}{c}{ Antall } \\
7 & 414 & 339 & 753 & 321553 & 304591 & 626144 \\
16 & 328 & 259 & 587 & 314388 & 299319 & 613707 \\
18 & 317 & 252 & 569 & 312963 & 298268 & 611231 \\
25 & 316 & 252 & 568 & 312450 & 297958 & 610408 \\
27 & 303 & 246 & 549 & 308639 & 294868 & 603507 \\
& 301 & 244 & 545 & 306940 & 293382 & 600322 \\
0 & & & & Prosent & & \\
7 & 100,0 & 100,0 & 100,0 & 100,0 & 100,0 & 100,0 \\
16 & 79,2 & 76,4 & 78,0 & 97,8 & 98,3 & 98,0 \\
18 & 76,6 & 74,3 & 75,6 & 97,3 & 97,9 & 97,6 \\
25 & 76,3 & 74,3 & 75,4 & 97,2 & 97,8 & 97,5 \\
27 & 73,2 & 72,6 & 72,9 & 96,0 & 96,8 & 96,4 \\
\hline
\end{tabular}

* I live og bosatt $=$ Fratrukket døde og utvandrete

Tabell 5. Høyeste utdanning ved 25-års alder for fødte i Norge 1967-76, sannsynlig Down syndrom og alle andre.

\begin{tabular}{lrrrrrr}
\hline \multirow{2}{*}{ Kategori } & \multicolumn{3}{c}{ Sannsynlig Down syndrom } & \multicolumn{3}{c}{ Alle andre } \\
\cline { 2 - 8 } & Menn & Kvinner & I alt & Menn & Kvinner & I alt \\
\hline I live/bosatt 25 år, Antall & 303 & 246 & 549 & 308609 & 294842 & $603451^{*}$ \\
Utdanningsnivå, Prosent & & & & & & \\
$0,9 \quad$ Ingen utdanning + uoppgitt & 14,5 & 7,7 & 11,5 & 0,4 & 0,3 & 0,4 \\
$1-4 \quad$ Videregående, avsluttende og lavere & 85,5 & 92,3 & 88,5 & 64,8 & 56,6 & 60,8 \\
$5-8 \quad$ Påbygging til videreg. og høyere & 0,0 & 0,0 & 0,0 & 34,7 & 43,1 & 38,8 \\
\hline
\end{tabular}

* manglende verdier 46

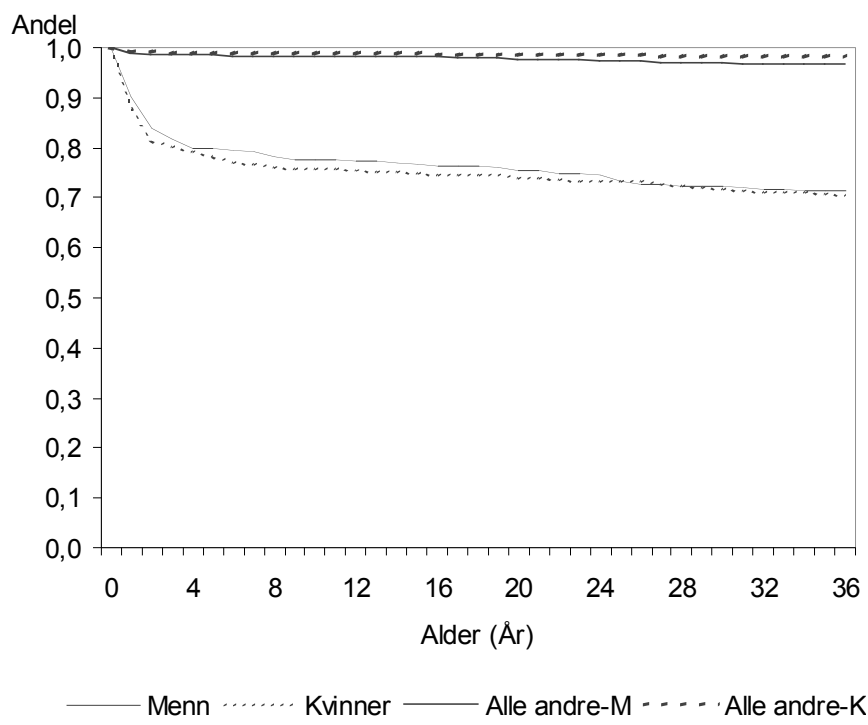

Figur 1. Overlevelse av fødte i Norge 1967-76 frem til og med 2003 med mest sannsynlig Down syndrom og alle andre, etter kjønn.

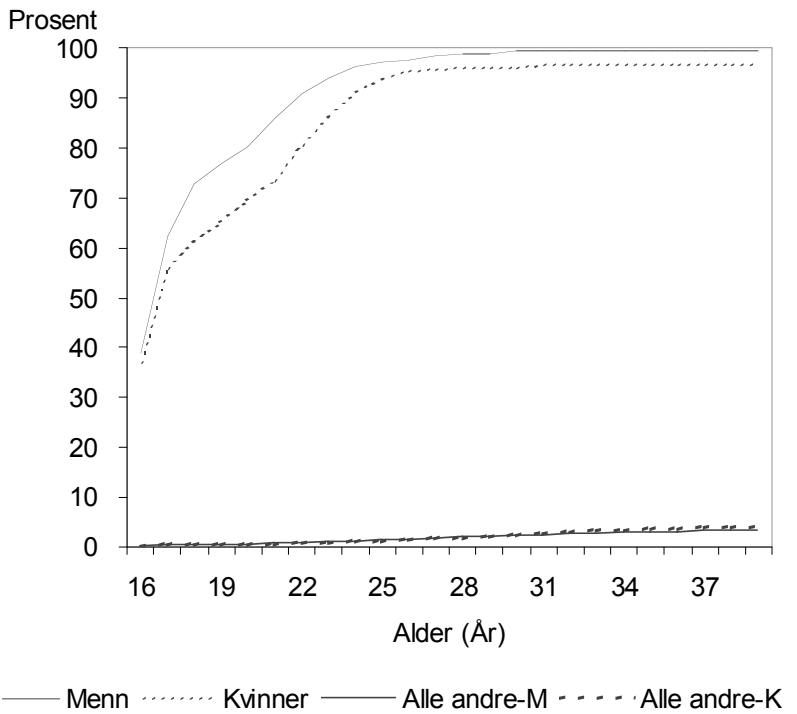

Figur 2. Uførepensjonering av fødte i Norge 1967-76 frem til og med 2006 med mest sannsynlig Down syndrom og alle andre, etter kjønn. 
Tabell 6. Særskilt tilrettelagt utdanning for fødte i Norge 1967-76 i live og bosatt 25-år med sannsynlig Down syndrom og alle andre.

\begin{tabular}{|c|c|c|c|c|c|}
\hline \multirow{2}{*}{\multicolumn{2}{|c|}{ Særskilt tilrettelagt utdanning }} & \multicolumn{2}{|c|}{ Down syndrom (prosent) } & \multicolumn{2}{|c|}{ Alle andre (prosent) } \\
\hline & & Menn & Kvinner & Menn & Kvinner \\
\hline \multirow[t]{2}{*}{ Kode nr. } & Kategori & $\mathrm{N}=303$ & $\mathrm{~N}=246$ & $\mathrm{~N}=308639$ & $\mathrm{~N}=294868$ \\
\hline & Ikke særskilt tilrettelagt & 9,2 & 13,4 & 89,4 & 90,3 \\
\hline 301101 & Allmenne, økonomisk, administrative fag & 3,0 & 2,4 & 0,1 & 0,1 \\
\hline 315901 & Musikk, dans, drama & 0,7 & 0,8 & 0,0 & 0,0 \\
\hline 316904 & Formgivingsfag & 2,6 & 7,7 & 0,1 & 1,0 \\
\hline 342199 & Handel & 0,0 & 0,0 & 0,3 & 0,5 \\
\hline 343299 & Kontorfag & 2,3 & 1,6 & 0,7 & 1,7 \\
\hline 355102 & Elektrofag & 0,0 & 0,0 & 0,6 & 0,1 \\
\hline 355207 & Kjøretøy, mekaniker & 0,0 & 0,0 & 0,5 & 0,0 \\
\hline 355209 & Maskinfag & 0,3 & 0,0 & 0,5 & 0,0 \\
\hline 355211 & Mekaniske fag & 5,6 & 0,8 & 2,9 & 0,2 \\
\hline 355214 & Reservedelsfaget for kjøretøy & 0,0 & 0,0 & 0,0 & 0,0 \\
\hline 357103 & Byggfag & 0,3 & 0,0 & 1,2 & 0,1 \\
\hline 357115 & Tekniske byggfag & 0,3 & 0,0 & 0,3 & 0,1 \\
\hline 358104 & Hotel- og næringsmiddelfag & 3,0 & 2,8 & 0,4 & 0,8 \\
\hline 358108 & Kokkfag & 0,3 & 1,2 & 0,3 & 0,6 \\
\hline 358309 & Kjøttfag & 3,0 & 0,4 & 0,3 & 0,1 \\
\hline 359999 & Naturvitenskapelige fag, håndverk, teknikk & 1,0 & 0,4 & 0,5 & 0,2 \\
\hline 368101 & Idrettsfag & 0,0 & 0,0 & 0,0 & 0,0 \\
\hline 369902 & Helse- og sosialfag & 9,9 & 10,2 & 0,2 & 2,9 \\
\hline 369909 & Husstell & 10,9 & 16,7 & 0,0 & 0,2 \\
\hline 369999 & Helse-, sosial-, idrettsfag & 3,3 & 5,3 & 0,1 & 0,3 \\
\hline 371199 & Fiske- og havbruk & 0,0 & 0,0 & 0,0 & 0,0 \\
\hline 373199 & Gartneri, hagebruk & 0,0 & 0,0 & 0,0 & 0,0 \\
\hline 379904 & Naturbruk & 1,0 & 0,4 & 0,5 & 0,1 \\
\hline 381399 & Maritime-, navigasjonsfag & 0,7 & 0,0 & 0,2 & 0,0 \\
\hline 381402 & Transport & 0,0 & 0,0 & 0,1 & 0,0 \\
\hline 399901 & Allmenn fag, bo- og arbeidstrening & 28,4 & 28,0 & 0,4 & 0,2 \\
\hline \multirow[t]{2}{*}{999999} & Uoppgitt & 14,2 & 7,7 & 0,5 & 0,3 \\
\hline & Total & 100,0 & 100,0 & 100,0 & 100,0 \\
\hline
\end{tabular}

utdanninger og de fleste (nær 90 prosent) med sannsynlig Down syndrom og kjent utdanning har fulgt slik utdanning (tabell 6).

Når det gjelder alle andre er det bare om lag 10 prosent som får særskilt tilrettelagt utdanning.

\section{Arbeidsaktivitet ved 27-års alder}

Som arbeidsaktiv er definert en person med en pensjonsgivende inntekt på $0,5 \mathrm{G}$ eller mer et bestemt år. Etter denne definisjon var det bare 14 menn $(4,7 \%)$ og 17 kvinner (7,0\%) med sannsynlig Down syndrom som var arbeidsaktive i 27-års alderen (tabell 7). Deres gjennomsnittlige pensjonsgivende inntekt var svært lav, $0,60 \mathrm{G}$ for menn og 1,33 for kvinner. Arbeidsaktiviteten for alle andre var vel 75 prosent for menn og 70 prosent for kvinner. Den gjennomsnittlig pensjonsgivende inntekt var 5,20 G for menn, 1/3 høyere enn for kvinner som hadde en gjennomsnittlig pensjonsgivende inntekt på 3,90 G.

Prosent arbeidsaktive ved 27-års alder sett i forhold til høyeste utdanning i 25-års alder er vist i tabell 8 . Tallene for Down syndrom blir små når utdanning spesifiseres på type av særskilt tilrettelagt utdanning og er derfor angitt etter gruppering av den særskilte utdanning som "yrkesrettet" og "ikke yrkesrettet". Særskilt tilrettelagt utdanning for personer med Down syndrom synes ikke å gi noen vesentlig uttelling i forhold til arbeidsaktivitet i 27-års alderen (tabell 8). De er i langt mindre grad arbeidsaktive enn alle andre som har fått tilsvarende særskilt tilrettelagt utdanning (for menn 4,7 prosent mot 75,9 og for kvinner 7,0 prosent mot 69,9).

\section{Antall barn registrert frem til 1998}

Barnefødsel er tatt som uttrykk for familiedannelse. For menn med sannsynlig Down syndrom er det ingen som er registrert med barn i MFR frem t.o.m. 1998, mens det var seks kvinner $(2,4 \%)$ med minst ett barn, tabell 9. For alle andre er prosenten med minst ett barn 43,0 og 60,7 for henholdsvis menn og kvinner. 
Tabell 7. Antall og prosent arbeidsaktive ved 27-års alder og gjennomsnittlig pensjonsgivende inntekt blant fødte i Norge 1967-76 med sannsynlig Down syndrom og alle andre.

\begin{tabular}{|c|c|c|c|c|}
\hline & \multicolumn{2}{|c|}{ Down syndrom } & \multicolumn{2}{|c|}{ Alle andre } \\
\hline & Antall & Prosent & Antall & Prosent \\
\hline Antall menn; I live/bosatt 27 år & 301 & 100,0 & 306940 & 100,0 \\
\hline \multicolumn{5}{|l|}{ Pensjonsgivende inntekt (G), gruppert } \\
\hline$<0,5$ G Ikke arbeidsaktiv & 287 & 95,3 & 74095 & 24,1 \\
\hline $\mathrm{G} \geq 0,5 \mathrm{G}$ Arbeidsaktiv & 14 & 4,7 & 232845 & 75,9 \\
\hline Gjennomsnittlig inntekt $(\mathrm{G})$ for arbeidsaktive & \multicolumn{2}{|c|}{0,60} & \multicolumn{2}{|c|}{5,20} \\
\hline Antall kvinner: I live/bosatt 27 år & 244 & 100,0 & 293382 & 100,0 \\
\hline \multicolumn{5}{|l|}{ Pensjonsgivende inntekt $(\mathrm{G})$, gruppert } \\
\hline$<0,5 \mathrm{G}$ Ikke arbeidsaktiv & 227 & 93,0 & 88409 & 30,1 \\
\hline $\mathrm{G} \geq 0,5 \mathrm{G}$ Arbeidsaktiv & 17 & 7,0 & 204973 & 69,9 \\
\hline Gjennomsnittlig inntekt $(\mathrm{G})$ for arbeidsaktive & \multicolumn{2}{|c|}{1,33} & \multicolumn{2}{|c|}{3,90} \\
\hline
\end{tabular}

Tabell 8. Antall og prosent arbeidstakere etter særskilt tilrettelagt utdanning blant fødte i Norge 1967-76 og bosatt ved 27-års alder med Down syndrom og alle andre.

\begin{tabular}{|c|c|c|c|c|c|c|c|c|}
\hline \multirow[b]{3}{*}{ Utdanning } & \multicolumn{4}{|c|}{ Menn } & \multicolumn{4}{|c|}{ Kvinner } \\
\hline & \multicolumn{2}{|c|}{ Down syndrom } & \multicolumn{2}{|c|}{ Alle andre } & \multicolumn{2}{|c|}{ Down syndrom } & \multicolumn{2}{|c|}{ Alle andre } \\
\hline & Antall & $\begin{array}{c}\text { Arb.takere } \\
(\%)\end{array}$ & Antall & $\begin{array}{c}\text { Arb.takere } \\
(\%)\end{array}$ & Antall & $\begin{array}{c}\text { Arb.takere } \\
(\%)\end{array}$ & Antall & $\begin{array}{c}\text { Arb.takere } \\
(\%)\end{array}$ \\
\hline Vanlig & 35 & 20,0 & 274543 & 76,4 & 56 & 35,7 & 264978 & 71,0 \\
\hline \multicolumn{9}{|l|}{ Særskilt tilrettelagt: } \\
\hline Ikke yrkesrettet & 91 & 2,2 & 1528 & 43,7 & 104 & 3,8 & 13505 & 58,6 \\
\hline Yrkesrettet & 56 & 8,9 & 28458 & 76,1 & 19 & 15,8 & 13411 & 65,0 \\
\hline Allmennfag, bo- og arb.trening & 85 & 7,1 & 1078 & 26,3 & 69 & 8,7 & 653 & 15,3 \\
\hline Alle særskilt tilrettelagt & 232 & 5,6 & 31064 & 72,8 & 192 & 6,8 & 27569 & 60,7 \\
\hline Uoppgitt & 53 & 9,4 & 1333 & 40,1 & 19 & - & 835 & 24,9 \\
\hline Totalt & 308 & 2,3 & 306940 & 75,9 & 267 & 12,4 & 293382 & 69,9 \\
\hline
\end{tabular}

Tabell 9. Prosent av fødte i Norge 1967-76 med minst ett barn registrert i MFR frem t.o.m. 1998 etter kjønn og sannsynlig Down og alle andre.

\begin{tabular}{lcc}
\hline & Down syndrom & Alle andre \\
\hline Menn i live/bosatt 16 a r & 317 & 313288 \\
Registrert med minst ett barn & 0 & 134590 \\
Prosent & 0,0 & 43,0 \\
Kvinner i live/bosatt 16 år & 252 & 298543 \\
Registrert med minst ett barn & 6 & 181289 \\
Prosent & 2,4 & 60,7 \\
\hline
\end{tabular}

\section{DISKUSJON}

MFR og NAV er langt fra perfekte datakilder for å estimere forekomsten av Down syndrom. Antas at den foretatte analyse har gitt et rimelig korrekt estimat av forekomsten av Down syndrom er sensitiviteten av diagnostikken som ligger til grunn for registrering av diagnosen i MFR 72,0 prosent; 67,8 for gutter og 77,2 for piker. Disse anslag forutsetter at korreksjonen av svikten i diagnoseregistreringen i NAV er korrekt. Et system for dobbel registrering av misdannelser ga et anslag på $58 \%$ for Down syndrom i MFR (10). I tillegg kommer at validiteten av de registrerte diagnoser er usikker. Når personer med diagnosen bare fra MFR blir uførepensjonert med diagnoser som angir andre spesifiserte misdannelser og uspesifisert oligofreni kan det dekke over at det foreligger Down syndrom. Tilgang til kromosomanalyser ville kunne avklare slike tvilstilfeller, men ikke problemet med falske negative, dvs. tilfeller av Down syndrom som ikke blir diagnostisert eller registrert i MFR eller NAV.

Forutsatt at meldesvikten i MFR for en spesifisert misdannelse er konstant over tid og at bortfallet er kjent, inklusive bortfallet ved fosterindisert abort $(11,12)$, vil registreringene i MFR kunne nyttes i estimering av forekomsten av misdannelsen. Men meldesvikten og bortfallet vil variere fra sted til sted og over tid. For estimering av prevalens ved fødsel er det viktig å være klar over de endringer i disse forhold som finner sted til en hver tid. Det krever systematisk samkjøring med i hvert fall en uavhengig diagnose- 
kilde i tillegg til MFR. NAVs stønadsregistre er en tilgjengelig kilde. Registreringen av diagnoser i disse stønadsregistre svikter imidlertid i ganske stort omfang og validiteten av diagnosene er usikker. NAVs stønadsregistre regnes formelt sett ikke som helseregistre men inneholder vesentlig informasjon om konsekvenser av sykdom. De ville kunne gi et verdifullt bidrag til vurdering av sykdommers forekomst og til at kostnader om sykeligheten ble bedre dokumentert.

En oppfølging, på den annen side, krever identifiserte tilfeller og at bortfallet ikke er selektivt. Vi har ikke hatt data til å vurdere en eventuell seleksjon. Dødeligheten ved Down syndrom er høy, særlig i de første leveår, svarende til hva som er rapportert fra andre steder (13). De aller fleste med Down syndrom får spesielt tilrettelagt utdanning, men denne utdanning fører ikke til deltagelse i arbeidslivet i nevneverdig grad. Det kan være flere grunner til det. En grunn kan være at programmet "Inkluderende arbeidsliv" (14) ikke har tatt høyde for personer med Down syndrom. Løsningen for de aller fleste er blitt uførepensjon. Men det er to menn og ni kvinner som ikke er registrert med uførepensjon frem til 30-39-års alderen. For disse kan diagnosen Down syndrom være feil, eller det kan være at diagnosen ikke er registrert i NAVs stønadsregistre. En avklaring på dette spørsmål er viktig for vurdering av levekårene for personer med Down syndrom. Men den konsesjon Datatilsynet har gitt for undersøkelsen tillater ikke videre oppfølging. Mange spørsmål må forbli ubesvart.

Takk til Ola Thune, NAV for bidrag i tilretteleggingen av datafilen og til Geir A. Skjeret, Forsvarets sanitet for datateknisk hjelp i analysene.

\section{REFERANSER}

1. Mellbye F. Medisinsk registrering av fødsel. Tidskr Nor Loegeforen 1967; 87: 1085-6.

2. Bjerkedal T, Bakketeig LS, Lillestøl J. Endringer i forekomsten av medfødte misdannelser, prematuritet og dødfødsel. Universitetet i Bergen, 1971.

3. Bjerkedal T. The medical birth registry of Norway. In: Mednick SA, Baert AE, red. Prospective longitudinal research: An empirical basis for the primary prevention of psychosocial disorders. Published on behalf of the World Health Organization Regional Office for Europe: Oxford University press, 1981: 58-60.

4. Bjerkedal T, Bakketeig L. Medisinsk registrering av fødsel i Norge i 5-års perioden 1967-71 (Medical Registration of Births in Norway during the 5-Year Period 1967-71). Institute of Hygiene and Social Medicine, University of Bergen, Norway, 1975.

5. Medisinsk fødselsregister. Fødsler i Norge 2003-2004. Årsrapport 2003-2004. Medisinsk fødselsregister, Nasjonalt folkehelseinstitutt i samarbeid med Universitet i Bergen, 2006.

6. Irgens LM. Medisinsk fødselsregister - et sentralt utgangspunkt for perinatalmedisinsk forskning. Tidsskr Nor Lageforen 2002; 112: 1546-9.

7. www.lovdata.no. Forskrift- Sentrale forskrifter. Medisinsk fødselsregister; Forskrift om innsamling og behandling av helseopplysninger i Medisinsk fødselsregister.

8. Statistisk sentralbyrå. Norsk standard for utdanningsgruppering. Revidert 2000. Statistisk sentralbyrå: OsloKongsvinger, 2001.

9. Medisinsk fødselsregister. Fødsler i Norge gjennom 30 år. Medisinsk fødselsregister: Bergen, 1999.

10. Lie RT, Heuch I, Irgens LM. Maximum likelihood estimation of the proportion of congenital malformations using double registration systems. Biometrics 1994; 50: 433-44.

11. Irgens LM. Svangerskapsavbrudd etter prenatal diagnostikk - meldeplikt og meldesvikt. Tidsskr Nor Lageforen 1993; 113: 3124-5.

12. Khoshnood B, De Vigan C, Blondel B. Advances in medical technology and creation of disparities: The case of Down syndrome. Am J Public Health 2006; 96: 2139-44.

13. Rasmussen SA, Wong LW, Correa A, Cambrell D, Friedman JM. Survival in infants with Down syndrome, Metropolitan Atlanta, 1979-1998. J Pediat 2006; 148: 806-11.

14. Arbeids- og administrasjonsdepartementet. St.prp.nr.1, tillegg nr.1 (2001-2002). Intensjonsavtalen om et inkluderende arbeidsliv - budsjettmessige konsekvenser mv. 